\title{
INTRODUKSI IPTEKS PADA PETERNAKAN SAPI DI KELOMPOK TANI RAWANG SAIYO DAN KELOMPOK TANI TUAH SEPAKAT
}

\author{
Simel Sowmen, Khasrad dan Rusdimansyah \\ Fakultas Peternakan Universitas Andalas. \\ Email: simel.hanna@gmail.com
}

Received: 30 Juni 2018. Accepted:02 Agustus 2018. Published Online 13 September 2018

\begin{abstract}
ABSTRAK
Tujuan kegiatan ini adalah untuk menumbuhkan swadaya masyarakat dalam usaha peternakan sapi potong dan pemanfaatan lahan untuk kebun rumput atau pastura; mencoba mengatasi permasalahan kondisi kandang yang belum memadai, kekurangan stok air akibat penampung air yang bocor dan sumber air yang jauh, lamanya proses pengolahan kotoran akibat kurang memadainya tempat pengolahan kotoran, kekurangan hijauan yang terjadi saat musim kemarau karena banyak tanaman hijauan yang mati. Program ini dilakukan dengan metode penyuluhan, diskusi terfokus, percontohan dan pelatihan. Metode pelaksanaan ipteks dilakukan dengan menerapkan sejumlah teknologi sesuai permasalahan yang ada yaitu perbaikan kandang, perbaikan tempat pengolahan kotoran dan penampung air serta peningkatan produksi pastura alam dengan introduksi leguminosa cover crop, usaha pengadaan air ke kelompok tani sehingga dapat menjamin kelangsungan usaha peternakan sapi. Pemanfaatan jerami padi yang merupakan by product dari sawah yang berada dekat kelompok tani melalui teknologi amoniasi jerami sehingga dapat digunakan sebagai alternatif pengganti hijauan.
\end{abstract}

Kata Kunci : hijauan pakan, sapi potong, Rawang Saiyo, Tuah Sepakat

\section{Introduction of Technology on Cattle Farm at Rawang Saiyo Farmer Group and Tuah Sepakat Farmer Group}

\begin{abstract}
The activities of devotion for farmers group Rawang Saiyo and farmer groups Tuah Sepakat in Solok Regency and South Solok Regency of West Sumatra with objective to cultivate a farm beef cattle and utilization the land for pastura; tryng to overcome the problem of inadequate enclosure conditions, lack of water stock due to leaking water reservoirs and distant water sources, the length of the sewage treatment process due to inadequate processing of sewage, lack of forage that occurs during dry season. This program is carried out with counseling methods, focused discussions, piloting and training. Science and technology implementation method is carried out by applying a number of technologies according to existing problems, namely cage repair, repair of sewage treatment plants and water reservoirs and increased production of natural pastures with the introduction of cover crop legumes, water procurement efforts to farmer groups so as to ensure the sustainable of cattle farming. Utilization of rice straw which is a by product of rice fields that are near farmer groups through straw ammonia technology so that it can be used as an alternative to forage.
\end{abstract}

Keywords: forage fodder, beef cattle, Rawang Saiyo, Tuah Sepakat

\section{PENDAHULUAN}

Pemerintah Provinsi Sumatera Barat saat ini sedang giat-giatnya untuk meningkatan populasi dan produktivitas ternak sapi dalam upaya mendukung program pemerintah dalam mewujudkan swasembada daging nasional. Hal ini ditandai dengan program "sejuta Simmental" yang diluncurkan beberapa tahun yang lalu. Selain itu juga didukung dengan program bantuan bagi kelompok tani ternak berupa pengadaan sapi untuk program pembibitan. Selain program Sarjana Membangun Desa (SMD) yang juga 
cukup lama berjalan. Dari sekian banyak program tersebut, terpantau hanya beberapa kelompok peternak yang kegiatannya masih berjalan, sehingga keberlanjutan program tersebut kurang terlihat.

Diantara penyebab kurangnya keberlanjutan program pemerintah tersebut adalah faktor keterbatasan pengetahuan dan keterampilan peternak dalam menggoptimalkan usaha ternak sapi. Diantara permasalahan yang dihadapi peternak pembibitan sapi potong adalah: manajemen pemeliharaan yang kurang baik, ketersediaan pakan yang kurang memadai, rendahnya nilai gizi pakan yang diberikan, pengetahuan birahi yang masih kurang, penanganan penyakit dan kurangnya pemanfaatan urin dan feses ternak sapi. Padahal, jika urin dan feses dapat dikelola dengan baik, akan memberikan tambahan penghasilan bagi peternak.

Berdasarkan kondisi tersebut, maka untuk mengoptimalisasi usaha pembibitan sapi potong dan penerapan Ipteks Bagi Masyarakat, telah dipilih dua kelompok tani yang benar-benar membutuhkan indtroduksi Ipteks. Terpilihlah dua kelompok tani yang akan dijadikan tempat kejasama yaitu, Kelompok Tani Rawang Saiyo yang terletak Jorong Balai Pinang, Nagari Muaro Paneh Kec. Bukit Sundi yang berbatasan langsung dengan kenagarian Koto Baru, Kecamatan Kubung Kabupaten Solok dan Kelompok Tani Tuah Sepakat yang terletak di Jorong Mato Aia, Kenagarian Bomas Koto Baru Kabupaten Solok Selatan.

Kelompok Tani Rawang Saiyo dan Kelompok Tani Tuah Sakato, merupakan kelompok peternak yang bergerak dibidang pembibitan sapi potong. Kedua Kelompok peternak ini mempunyai sistem pemeliharaan dan jenis sapi yang dipelihara berbeda. Kelompok Rawang Saiyo memelihara sapi peranakan Simmental dan sapi Pesisir secara semi intensif dengan sistem perkawinan secara Inseminasi Buatan (IB), sedangkan Kelompok Tani Tuah Sepakat memelihara sapi Bali secara intensif dengan sitem perkawinan secara alami.

\section{Kelompok Tani Rawang Saiyo}

Lahan kelompok tani Rawang Saiyo berada di Rawang Setan, Jorong Balai Pinang, Nagari Muaro Paneh Kec. Bukit Sundi yang berbatasan langsung dengan Nagari Koto Baru. Lahan ini +/- $2 \mathrm{Km}$ dari jalan Lintas Sumatera Solok-Padang km 6 Koto Baru dan +/- $5 \mathrm{Km}$ dari pasar ternak Muaro Paneh.

Dengan luas lahan Kelompok 8 Ha, untuk ternak sapi 3 Ha, 5 Ha sudah di Tanami dengan mahoni, karet dan Jabon. Kandang Semi Permanen ada 4 bh kandang dengan kapasitas 40 ekor sapi, 1 bh gudang, 2 bh pondok kerja, sarana listrik dan PDAM sudah ada dengan jumlah sapi sebanyak 20 ekor , 2 ekor jantan dan 18 ekor betina dengan jenis sapi lokal. Lahan pengembalaan sapi $1 \mathrm{Ha}$ dan Lahan rumput potong 0,5 $\mathrm{Ha}$ tapi sekarang lahan rumput potong dalam keadaan kritis disebabkan kemarau tahun lalu (2014) dimana pada saat musim kemarau lahan menjadi sangat kering dan sumber air untuk lahan rumput tidak ada inilah yang menjadi kendala bagi kelompok ini.

Kelompok Tani Rawang Saiyo memelihara ternak dengan tujuan pembibitan dengan sitem pemeliharaan semi intensif, dimana siang hari dilepas di padang pengembalaan dan sore hari dikandangkan, jenis sapi yang dipelihara sebagaian besar adalah sapi Pesisir dan sebagian sapi persilangan Limosin. Berdasarkan pantauan Kami, kondisi sapi sebagaian besar dalam keadaan kurus dan bahkan ada yang mengalami gangguan reproduksi yaitu sulit bunting dan ada yang tidak menunjukkan gejala birahi, padahal sudah berumur lebih dari 3 tahun. 
Walaupun ada pemberian pakan penguat, tapi jumlah dan kualitasnya masih kurang. Sementara itu pakan hijauan masih terbatas dan kualitasnya rendah, karena hanya mengandalkan rumput lapangan saja, bukan rumput unggul. Pemanfaatan leguminosa juga belum dilakukan. Sementara itu pada musim kemarau, ketersediaan rumput sangat terbatas dan terjadi kekurangan air. Ini merupakan kendala utama masyarakat di daerah ini. Padahal kelompok ini sebenarnya bisa memanfaatkan jerami padi yang berasal dari lingkungang sekitar, namun hal ini belum dilakukan. Selain itu pengelolaan ternak masih dirasa kurang karena pemandian sapi yang masih jarang akibat keterbatasan sumber air.

\section{Kelompok Tani Tuah Sepakat}

Kelompok Tani Tuah Sepakat Jorong Mato Aia, wilayahnya termasuk ke dalam Kecamatan Sungai Pagu Kabupaten Solok Selatan Provinsi Sumatera Barat. Mato Aia dikenal sebagai sebagai kawasan pertanian, sebagian besar penduduknya bekerja sebagai petani. Kelompok Tani Tuah Sepakat berdiri sejak 19 Desember 2006 sesuai dengan SK Wali Nagasi Bomas Koto Baru Nomor: 440/90/BMS/IV-2011 yang beranggotakan sebanyak 19 orang.

Kelompok Tani Tuah Sepakat saat ini diketuai oleh Bapak Samsul Bahri yang merupakan mantan Kepala Desa. Mata pencaian anggota kelompok tani ini adalah sebagai petani sawah dengan hasil utama padi. Sejak Juli 2014, kelompok ini mendapatkan bantuan sebanyak 5 ekor sapi Bali yang terdiri dari 1 jantan dan 5 betina. Saat ini 3 ekor betina dalam keadaan bunting. Pada awal 2015 kelompok ini kembali memperoleh bantuan sapi Bali dari Dinas Pertanian, Peternakan dan Perikanan Kabupaten solok sebanyak 7 ekor, yang terdiri dari 1 jantan muda dan 6 ekor betina dara.

Luas tanah di lingkuangan kandang adalah 14 x 30 m yang merupakan lahan sewa. Bangun yang dimiliki terdiri sari $5 \times 6$ dan $7 \times 8$ bangunan kandang dan tempat kotoran semi permanen dan pengolahan kompos seluas $3 \times 6 \mathrm{~m}$ (permanen). Kelompok Tuah Sepakat memiliki satu unit mesin penggiling kompos dan satu 2 unit gerobak sorong. Bangunan semi permanen yang dimiliki bertiangkan bambu dan beratapkan terpal sehingga kurang kondusif.

Berdasarkan wawancara dengan anggota kelompok, mereka balum mengenal pakan konsentrat untuk sapi dan pemberian mineral juga belum dilakukan. Pakan sapi hanya mengandalkan rumput lapangan yang dicari dari sekitar pekarangan dan pematang sawah. Mereka juga belum mengenal pakan leguminosa. Sementara itu kotoran cair (urin) juga belum termanfaatkan.

Sumber air yang dimiliki belum memadai, karena mengandalkan air dari sawah yang kondisinya terbatas dan mereka belum memiliki tempat penampungan air. Pemeliharaan ternak sudah intensif, namun belum didukung pakan yang memadai. Pengelolaan ternak juga belum optimal, karena pemendian ternak dilakukan tidak teratur, hanya saat digiring ke padang pengembalaan 10 hari sekali. Sumber listrik yang dimiliki kelompok masih menumpang dari rumah penduduk.

Kelompok ini memiliki potensi yang besar dalam pengembangan ternak sapi potong karena berlokasi di dekat areal persawahan, dimana jerami padi yang dihasilkan bisa dimanfaatkan sebagai sumber pakan dan dipematang sawak bisa ditanamai dengan rumput unggul. Saat ini kelompok juga belum memiliki kebun rumput sendiri. 


\section{Permasalahan Mitra}

Berdasarkan diskusi dan wawancara dan ketua dan anggota kelompok mitra, maka dapat diidentifikasi masalalah yang dialami mitra yang perlu dicarikan solusinya, diantaranya adalah: kondisi kandang yang kurang layak, tempat pengolahan kotoran sapi yang kurang memadai, bak penampungan air yang kurang memadai sehingga tidak bisa digunakan, kelompok mitra belum memanfaatkan limbah hasil pertanian yang berpotansi dijadikan pakan ternak seperti: jerami, pengelolaan lahan perkebunan di sekitar kandang belum maksimal, sehingga bisa dilakukan penanaman hijauan pakan melalui pola tanam terintegrasi, rendahnya pengetahuan peternak dalam tatalaksana pemeliharaan ternak sapi yang baik.

Berdasarkan permasalahan-permasalahan mitra tersebut maka kegiatan ini memiliki target luaran sebagai berikut: perbaikan kandang; perombakan tempat penampung kotoran sehingga memudahkan dalam pengolahan kotoran menjadi pupuk organik; perbaikan bak penampung air sehingga bak dapat termanfaatkan secara optimal dan dapat mengatasi kendala kekurangan air saat musim kemarau; peningkatan produksi hijauan dari pasture alam; mendorong pengolahan dan pemanfaatan limbah hasil pertanian (jerami) sebagai pakan ternak; peternak mampu membudidayakan dan memanfaatkan leguminosae sebagai sumber protein murah dalam budidaya ternak sapi potong; peningkatan kemampuan dan pengetahuan peternak dalam tatalaksana pemeliharaan ternak sapi yang baik; dan peningkatan pendapatan peternak.

Kegiatan ini bertujuan untuk meningkatkan pengetahuan kelompok tani rawang saiyo dan kelompok tani tuah sepakat dalam tatalaksana pemeliharaan ternak sapi yang baik, mengintroduksikan tanaman legum pakan yang dapat dikembangkan pada lahan kering dan dapat diintegrasikan dengan tanaman perkebunan, melakukan pengolahan kotoran ternak dan teknologi pengolahan by product pertanian yang terdapat di areal sekitar kandang peternakan sapi sehingga dapat digunakan sebagai pakan alternatif saat kekurangan pakan hijauan, dan dapat meningkatkan pendapatan peternak.

\section{METODE}

Beberapa permasalahan petani sebagaimana dikemukakan di atas perlu segera diatasi guna meningkatkan taraf perekonomian masyarakat melalui efisiensi dan efektivitas penggunaan sumber daya yang mereka miliki. Untuk itu solusi terbaik yang dapat dilakukan adalah penerapan Sistem Pertanian Terpadu Berbasis Agribisnis, berupa kombinasi manfaat ternak sapi dengan sawah dan Limbah dari sawah (jerami) merupakan sumber pakan untuk ternak dan limbah dari ternak (feses dan urin) merupakan sumber unsur hara yang sangat baik bagi pertumbuhan padi sawah dan tanaman perkebunan yang ada di sekitar lokasi.

Introduksi IPTEK yang sangat dibutuhkan untuk mengatasi permasalahan diatas yang ditawarkan dalam kegiatan IbM ini adalah sebagai berikut:

1. Perbaikan kandang, perombakan tempat pengolahan kotoran.

2. Perbaikan penampung air, sehingga menjamin ketersediaan minum untuk ternak

3. Peningkatan produktifitas pastura alam dengan mengintroduksi tanaman legume yang tahan kekeringan dan dapat diintegrasikan dengan tanaman perkebunan.

4. Memanfaatkan by product pertanian seperti jerami padi sebagai pakan hijauan ternak melalui teknologi pengolahan amoniasi. 
5. Pengolahan kotoran ternak menjadi pupuk organik.

\section{Metode Pelaksanaan Kegiatan}

\section{- Penyuluhan}

Penyuluhan merupakan cara yang paling tepat dalam memberikan pengetahuan kepada peternak untuk memantapkan pelaksanaan kegiatan dan hasil penyuluhan, dengan menyiapkan brosur tentang teknik pemelharaan, recording, sistem reproduksi, teknik budidaya tanaman leguminosa sebagi seumber pakan.

\section{- Pelatihan dan Percontohan}

Memperagakan/mempercontohkan bagaimana pemilihan bahan pakan, membuat amoniasi jeramai, cara pembuatan pakan konsentrat dan teknik budidaya tanaman pakan leguminosae.

\section{- Bimbingan dan Pembinaan}

Peternak yang telah mulai menerapkan teknologi yang ditawarkan akan dibimbing dengan pembinaan yang dilakukan secara periodik melalui koordinasi dengan ketua kelompok.

\section{- Diskusi dan Konsultasi}

Pada saat penyuluhan, pelatihan/pecontohan dan pembinaan, selalu diadakan diskusi dan konsultasi untuk lebih memantapkan kegiatan yang dilaksanakan.

- Evaluasi dan Monitoring

Evaluasi terhadap kegiatan yang dilaksanakan dalam 3 tahap, yaitu:

- Evaluasi sebelum kegiatan, untuk mengetahui pengetahuan peternak sebelum dilaksanakan program.

- Saat kegiatan sedang berjalan,evaluasi dilakukan untuk mengetahui:

- Minat peternak terhadap kegiatan yang dilaksanakan

- Kemampuan peternak dalam menyerap materi yang diberikan

- Setelah kegiatan dilaksanakan, evaluasi dilakukan untuk mengetahui :

- Aspek-aspek kuantitatif peternak yang melaksanakan/menerapkan kegiatan ini.

- Pendapatan tambahan yang diperoleh peternak pemanfaat jerami padi.

\section{HASIL DAN PEMBAHASAN}

Kegiatan ini diawali dengan kunjungan ke lokasi mitra I yaitu kelompok tani ternak Rawang Saiyo yang berada di Lahan kelompok tani Rawang Saiyo berada di Rawang Setan, Jorong Balai Pinang, Nagari Muaro Paneh Kec. Bukit Sundi Kabupaten Solok yang dapat ditempuh dalam waktu \pm 1 jam 30 menit dari Kota Padang. Kunjungan selanjutnya adalah ke mitra II, yaitu kelompok tani Ternak Kelompok Tani Tuah Sepakat Jorong Mato Aia, wilayahnya termasuk ke dalam Kecamatan Sungai Pagu Kabupaten Solok Selatan. Dalam kunjungan terhadap kedua kelompok mitratersebut, tim melakukan analisa terhadap kondisi terkini dari mitra untuk penyelarasan rencana kegiatan yang diusulkan dengan kondisi mitra dan kesesuaian dana yang diterima.. Adapun kegiatan yang sudah dilaksanakan adalah: 


\section{Perombakan Tempat Penampungan Kotoran}

Kegiatan ini dilakukan di Kelompok Tani Rawang Saiyo, hal ini didasarkan pada tingginya permintaan akan pupuk kotoran sapi kering dari kecamatan tetangga, sementara kondisi penampungan kotoran yang ada belum memadai dan kurang mendukung dalam pengeringan kotoran sapi, maka dari itu dilakukan perbaikan terhadap tempat penampungan kotoran.
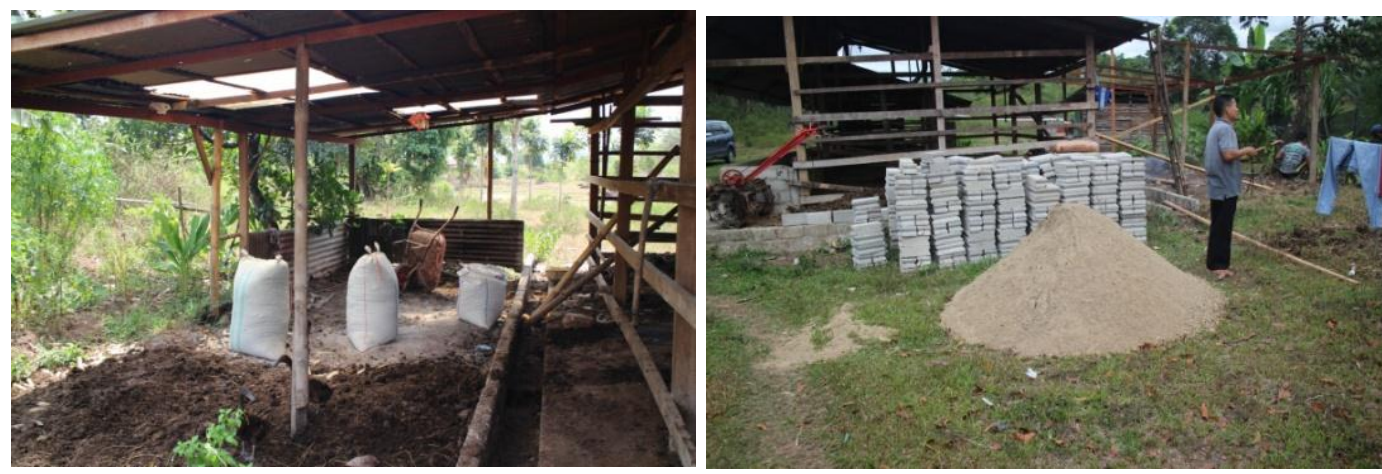

Gambar 1. Foto Material dan Proses Perombakan Tempat Pengampungan Kotoran

2. Pebaikan Kandang

Kegaitan ini dilakukan pada mitra II, yaitu Kelompok Tani Tuah Sepakat. Hal ini dilakukan karena kondisi kandang yang terbuat dari tiang bambu dan sebagian masih beratapkan terpal plastik, sehingga sangat rentan terjadinya kerusakan. Berdasarkan hal ini maka dilakukan pergantian tiang dan penggantian atap.

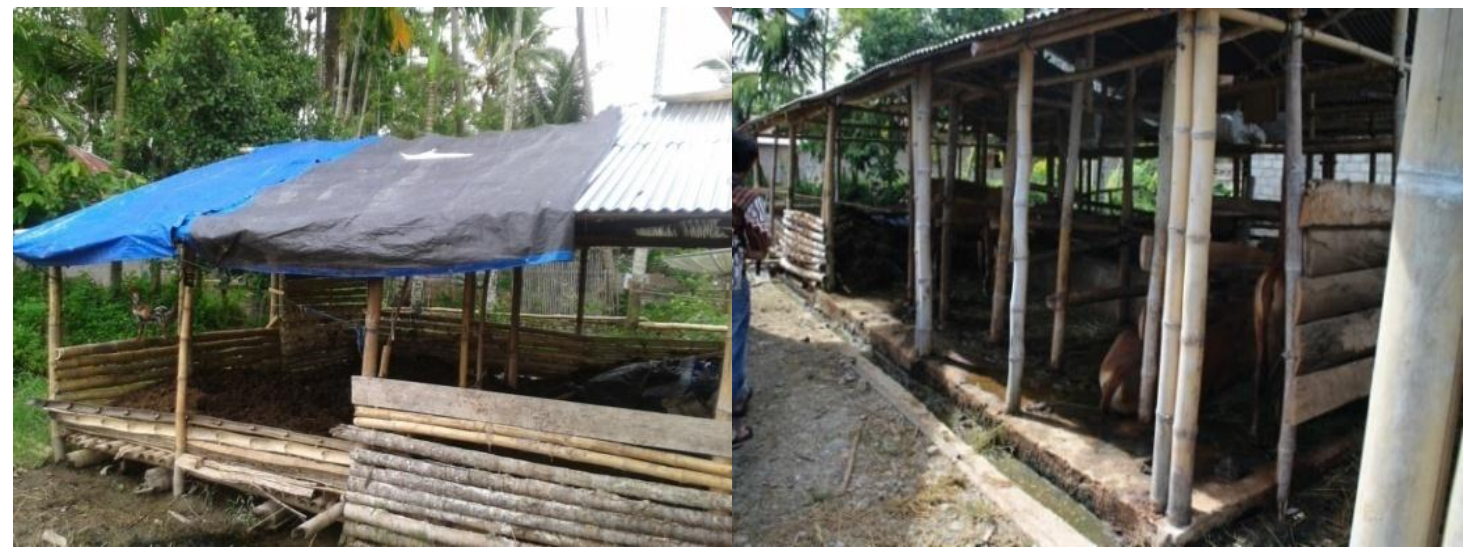

Gambar 2. Foto Kondisi Kandang Ternak di Kelompok Mitra II

3. Perbaikan Bak Penampung Air

Kegiatan ini dilakukan di Mitra I, hal didasari oleh kondisi penampungan air di kandang mitra I yang kurang memadai, sehingga tidak optimal dalam menampung air untuk kebutuhan minum ternak, kebersihan kandang dan juga ternak sapi. Perbaikan bak penampung air ini diharapkan juga dapat mengatasi masalah kekurangan air pada saat musim kemarau.

4. Optimalisasi Produksi Hijauan dari Pastura Alam

Kegiatan ini dilakukan di Mitra I, dimana mereka memiliki lahan pengembalaan 
alami sebagi sumber hijauan, namun produktivitasnya masih perlu ditingkatkan. Salah satu cara yang dilakukan adalah dengan pembersihan gulma yang berada di sekitar pastura alam dan menyebarkan benih legum terutama cover crop di pastura tersebut.
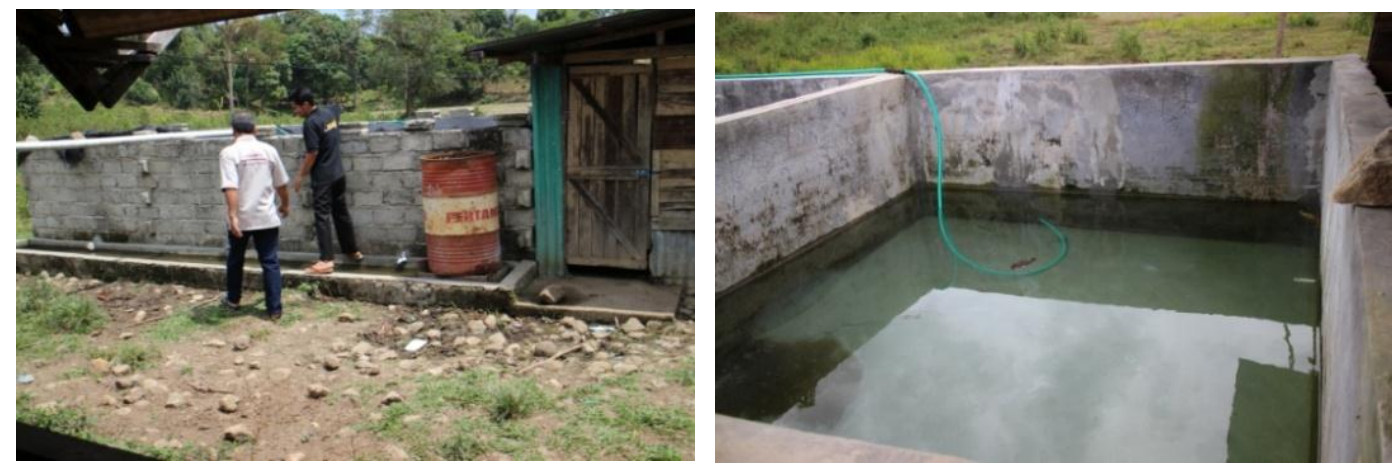

Gambar 3. Perbaikan Bak Penampung Air di Kelompok Mitra
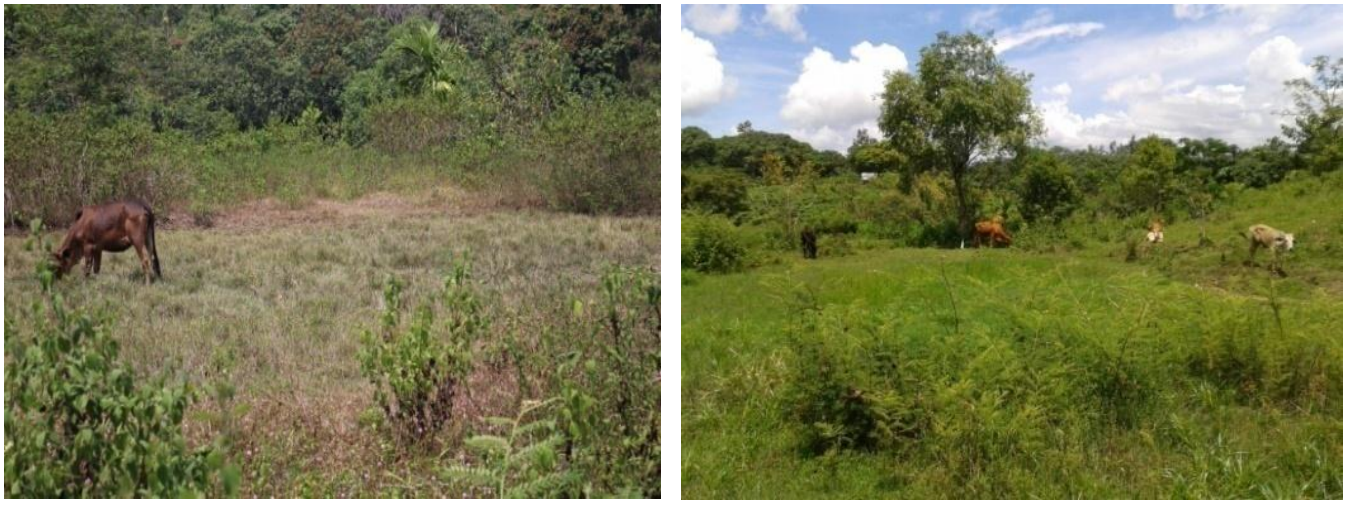

Gambar 4. Foto Padang Pengembalaan Alam di Mitra

\section{KESIMPULAN DAN SARAN}

Kegiatan yang telah dilakukan dapat membantu kelompok tani dalam menjalankan usaha peternakan sapi lebih optimal melalui sistem perkandangan yang seharusnya, perbaikan bak air, pemanfaatan kotoran ternak sebagai pupuk organik yang bernilai jual, peningkatan pastura alam yang berada di sekitar kandang sehingga ketersediaan hijauan pakan dapat ditingkatkan, dan pemanfaatan by product pertanian jerami padi sebagai sumber pakan alternatif saat musim kemarau nantinya. Saran untuk keberlanjutan program pada kelompok tani tersebut adalah perlu dicarikan sumber air untuk memenuhi kebutuhan air peternakan tersebut, perlu dibuat kebun rumput pakan melalui usaha budidaya tanaman pakan unggul yang tahan kekeringan (rumput dan pakan) dan memiliki produktivitas tinggi. 


\section{UCAPAN TERIMAKASIH}

Terima kasih kepada Direktorat Pendidikan Tinggi Kementerian Riset, Teknologi dan Pendidikan Tinggi yang telah mendanai kegiatan ini melalui IbM Peternakan Sapi di Kelompok Tani Rawang Saiyo dan Tuah Sepakat, tahun 2016.

\section{DAFTAR PUSTAKA}

Badan Pusat Statistik Kabupaten Solok Selatan. 2014. Kabupaten Solok Selatan Dalam Angka 2013. http://solokselatankab.bps.go.id/?hal=publikasi_detil\&id=1. Diakses tanggal 5 April 2015.

Badan Pusat Statistik Kabupaten Solok. 2015. Kecamatan Bukit Sundi Dalam Angka 2013. http://solokkab.bps.go.id/web/?hal=publikasi_detil \&id=66. Diakses tanggal 16 April 2015

Badan Pusat Statistik Kabupaten Solok Selatan. 2015. Kecamatan Pauh Duo Dalam Angka 2013. http://solokselatankab.bps.go.id/?hal =publikasi_detil\&id=7. Diakses tanggal 15 April 2015. 